Program on Education Policy and Governance Working Papers Series

\title{
Do (German) State Bond Markets Discount Politics?
}

Sounman Hong, Harvard University,

Sounman_Hong@hksphd.harvard.edu

Daniel Nadler, Harvard University,

Daniel.Nadler@gmail.com

Camillo von Muiller, University of St. Gallen,

Camillo.Freiherrvonmueller@unisg.ch

PEPG 12-01 


\title{
DO (GERMAN) STATE BOND MARKETS
}

\section{DISCOUNT POLITICS?}

\author{
Working Paper as of 2012-01-09
}

Sounman Hong

Harvard University, John F. Kennedy School of Government, 79 John F. Kennedy Street, Cambridge, MA 02138, Sounman_Hong@hksphd.harvard.edu

Daniel Nadler

Harvard University, Department of Government, 1737 Cambridge Street, Cambridge, MA 02138, Daniel.Nadler@gmail.com

Camillo von Müller ${ }^{1}$

University of St. Gallen, Institute of Management, Dufourstrasse 40a, CH-9000 St Gallen,

Camillo.Freiherrvonmueller@unisg.ch

\begin{abstract}
To what extent do bond market reactions to an unexpected deficit shock depend on state-specific politics? To answer this question, we calculate German state bond spreads over government benchmark paper using information from Datastream for the period 2006-2010. We test for a variety of institutional and political factors. We find evidence that investors base risk perceptions on state specific economic and institutional characteristics. Further, in left-leaning Eastern German states, an increase in unexpected deficit shock had a greater negative effect on a state's risk. JEL Codes: E62, G18, G24, H71, H72, H74, H76, H77, N24, and P43
\end{abstract}

\footnotetext{
${ }^{1}$ Corresponding Author
} 


\section{INTRODUCTION}

As the recent sovereign debt crisis unfolded, German states (Bundesländer) experienced significant changes in their fiscal circumstances, and their borrowing costs increased sharply. Substantial interstate differences in borrowing costs have also recently been seen. For example, the state of North Rhine Westphalai paid more than 80 basis points more on their state-level bonds than did other Western states in 2009. The relative yields on debt issuances by North Rhine Westphalia and Hamburg have diverged by as much as 120 basis points. Such significant disparities in German state-level borrowing costs are relatively unprecedented. Though they certainly reflect divergent state-level economic conditions that were amplified by the European sovereign debt crisis and the global recession, they may also reflect more 'structural' factors such as differences in state-level political institutions and regional patterns of public finance.

For example, Poterba \& Rueben (2001) show that in the 1990s yield spreads of US state bonds over federal benchmark instruments differed depending on the question whether a state's fiscal policy was subject to tight antideficit rules or not. Building on the methodological approach of Poterba \& Rueben (2001), Nadler \& Hong (2011) raise an analoguous question with regard to the issue whether yield spreads in US subnational bond markets reflected characteristics of state specific politics in the recent financial crisis. Federal and state governments are highly intertwined within the context of German fiscal federalism. As a consequence, the allocation of state revenues and expenditures is a highly political issue. We therefore analyze yield spreads in German state bond markets so as to find out in how far investors discount politics when assessing state specific credit risks. Given the dramatic economic disparities that continued to prevail between East and West Germany after reunification 1990 (Hunt 2000) our investigation also includes observations on regional differences in Germany. This approach is mainly motivated by Neuberger (1999) who reports that financing practices of German banks differed with regard to East and West German enterprises. Banks were often "too restrictive in their lending" toward East German companies in the decade after the fall of the Berlin wall. In light of the imbalanced economic and strucutral conditions that still separate Western and Eastern parts in Germany, we use the crisis of 2008-2010 as a testing ground for investigating whether state bond markets also discount for regional differences between East and West Germany.

\section{LITERATURE}

The general issue of government credit risks has been well researched in context of developed and developing economies (e.g. Edwards, 1984; Min, 1998, and Rowland \& Torres, 2004) both on national and subnational level (e.g. Capecci 1991, 1994; Alesina, De Broeck, Prati \& Tabellini 1992; and Bayoumi, Goldstein \& Woglom 1995). Credit risks have been discussed with respect to differences in states' fiscal performance as 
well as with regard to varying institutional factors (Baldacci, Gupta \& Mati (2011). Conceptual roots of the institutional approach reach back to Hibbs (1977) (Schmidt 1996; cf. also Seitz,2000). Studies like Alesina \& Sachs (1988) have complemented this approach focusing on informal factors such as differences in party politics to explain risk differences (Seitz 2000). Yet disagreements exist as to which part of the political spectrum delivers fiscal policies that are more sustainable (Roubini and Sachs 1989a, 1989b; Borreli \& Royed 1995; Seitz 2000; Ardagna 2004; Alesina, Ardagna, \& Trebbi 2006; Alesina, 2010). Other studies concentrate on correlations of fiscal institutions and state specific borrowing costs (e.g. Johnson \& Kriz 2005; Bayoumi, Goldstein \& Woglom 1992' 1995; and Lowry \& Alt 2001). In particular, investigations of Poterba \& Rueben $(1997,2001)$ on fiscal institutions and US state bond markets have stipulated further research such as the approach of Hallerberg \& Wolff (2008) who discuss sovereign risk premiums in EMU as result of diverging fiscal institutions and policy. Nadler \& Hong (2011) raise analoguous questions with regard to reaction of US state bond markets to state specific policies within the context of the recent financial crisis.

Despite Germany's economic relevance as one of the "pillars of global finance" (Laulajainen 1999, p.502) German state bond markets have received limited attention in the literature (Schulz \& Wolff, 2009). Studies on German subnational debt markets include the works of Lemmen (1999), Wolff (2008), Heppke-Falk \& Wolff (2008), Schulknecht, von Hagen, \& Wolswijk (2009), and Schulz \& Wolff (2009). Heppke-Falk \& Wolff (2008) and Schulz \& Wolff (2009) discuss in how far bond markets build their assessments of German state credit risks on the assumption of federal bailout guarantees. They base their investigations on bond data for the period of 1992 - 2007. Consequently, their analysis does not contain information on how the crisis of 2008- affected investor assumptions, nor can they account for recent institutional changes (c.f. Gröteke \& Mause, 2009). We hence regard the timing of Schulz \& Wolff 's (2009) study as an invitation for further research.

We pay particular attention to institutional factors as proposed by Alesina (2010), Poterba \& Rueben (1997, 2001) and Nadler \& Hong (2011). Motivated by existing studies which show that in private capital markets investor sentiments have been influenced by Germany's history and division into two different economic systems after WWII (BDI, 1994, Carlin \& Richthofen, 1995, Neuberger, 1999) we also test for investor perceptions with regard to differences between states in the territories of the old FRG and the former GDR.

\section{BACKGROUND}

Schulz \& Wolff (2009) provide a detailed picture of the history, structure and scope of German state bond markets. We aim at complementing their work by discussing in how far differences in institutions and politics impact the behavior of investors in these markets. Our research is focused on yield spreads of state bonds over government benchmark equivalents ("Bund") that we assume to represent investors' opinions with regard to "the 
subnational government's capacity and willingness to repay ... debt obligations in full and on time" (Liu \& Tan,p.4). In particular, we aim at understanding in how far investors perceive of formal and informal rules that govern the relations between central and state governments as determinants of state credit risks.

Fox (2002) observes that the German fiscal federal order undermines clear separations between state and central government competencies. As a consequence market participants differ in their opinions as to how far states bear individual credit risks. For example, Fitch Ratings (1999) rejects the notion that states can default assuming the existence of implied and unlimited bailout guarantees by the central government. Contrary to Moody's and S\&P (2001) that disagree on this issue, Fitch is hence issuing homogeneous credit ratings for the German federal and state governments (Nord/LB 2010; Rosenbaum 2008; Hildebrandt 2009; Seitz 2000; Laulajainen 1999). In two rulings of 1986 and 1992 the German Constitutional Court indeed decided that "federal ... transfers can be used to bail out fiscally troubled Länder" (Rodden 2003, p.180). The rulings are often interpreted as signal to financial markets that there is "a high chance of bailout of risky borrowers" (Seitz 2000, p.30). Yet, more recent rulings of the Constitutional Court in which the former rejected federal aid to states under financial distress question the approach of Fitch (1999) (Heppke-Falk \& Wolff 2008). In sum, arguments exist pro and contra the notion of German federalism as unlimited bailout regime. In light of these ambiguities, questions emerge in how far bond markets view state credit risks as reflections of the economic, fiscal and political environments of a given state. "[P]references and ideology of political parties [do not only] significantly affect fiscal policy" of governments (Seitz 1998, 0.184). Within the highly intertwined environment of fiscal federalism in Germany, the identity of the state-governing party might for example matter for the ability of a distressed state government to reach consensus with other state and federal governments so as to attract vertical and horizontal transfers for bailout.

In light of the existence of structural imbalances in reunified Germany investors might include additional factors into their calibrations of a state's willingness and ability to repay debt.

As of 2009, GDP per capita in East Germany had risen above $60 \%$ of West German levels but hourly labour costs remained $80 \%$ of those in the West. Wage differences and continuously high unemployment rates resulted in net emigration. "The populaion of the former GDR declined by 1.5 million people or $10 \%$ from 1991 to 2008, while the population of the former Federal Republic including West Berlin increased by 3.7 million" (Sinn \& Sinn, 2009). East Germany's "disappointing growth" (ibid.) becomes also apparent in international perspective. Between 1995 an 2009 the East German economy grew by $16.8 \%$ thus being outperformed in terms of growth rates by other former Eastern Block economies such as those of the Czech Republic (44.2\%), or Slovenia (66.5\%) (ibid.) In order to mitigate disparities between East and West German states and to stimulate the East German state economies, the federal government guaranteed in 2005 the continuation of transfers to East German states until the year of 2019 paying those funds out of the 156 
Billion Euros of the so-called "Solidarity Pact 2" in addition to existing transfers (Seitz 2006). Given the fact that East German states still received on average about a fifth of their revenues in form of transfers from the federal government between 2005 and 2009, we are interested in finding out if credit markets reflect regional differences between the East and the West in their decisions about the relative risk of Western and Eastern German state bonds.

\section{METHOD}

Our work follows Poterba and Rueben (2001) in defining budget "shocks" that are revealed within a state's fiscal year. Specifically, fiscal shocks are defined as

$$
\begin{gathered}
\text { Defshock }_{i t}=\text { Expshock }_{i t}-\text { Revshock }_{i t} \\
\text { Revshock }_{i t}=\text { Actual revenue }_{i t}-\Delta \text { Tax }_{i t}-\text { Forecast revenue }_{i t} \\
\text { Expshock }_{i t}=\text { Actual outlays }_{i t}-\Delta \text { Spend }_{i t}-\text { Forecast outlays }_{i t}
\end{gathered}
$$

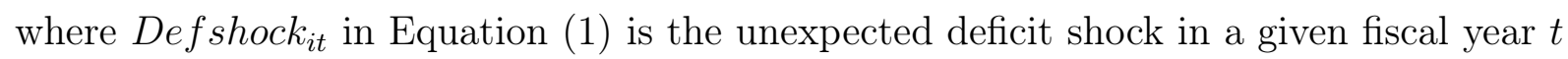
in state $i$, which is our measure of a budget "shock". The unexpected deficit shock equals the difference between unexpected revenue (Revshock $\left.k_{i t}\right)$ and unexpected expenditure $\left(\right.$ Expshock $\left._{i t}\right)$. Each component is defined by the difference between forecast revenues or expenditures before the beginning of the fiscal year and the revenues or expenditures that would have been collected during the fiscal year, given actual economic conditions.

As Poterba \& Rueben (2001) developed their framework for US contexts where horizontal and vertical transfers are less relevant than in the German fiscal equalization system, we also try unexpected change in transfers and debt instead of fiscal deficit shock defined in Equation (1), but as regression estimates were almost identical, we present our estimates with the fiscal deficit shock variable.

The central question of our interest is whether the bond market's reaction to an unexpected deficit shock depends on institutional and political factors. We begin our analysis by focusing on the share of "left political party" in state's legislature. In other words, we aim to estimate whether unexpected deficit shock is more easily transmitted to state's risk of default when the share of "left political party" is higher. To examine this question, we interact our measured unexpected deficit shock (Defshock it $_{\text {) }}$ with the share of "left political party" in state's legislature controlling for economic conditions each state has faced. The equation we estimate takes the form

$$
R_{i t}=\alpha+\beta_{1} \text { Defshock }_{i t}+\beta_{2}\left(\text { Defshock }_{i t} \text { East }_{i t}\right)+\beta_{3} X_{i t}+\beta_{4} \text { East }_{i t}+\beta_{5} S_{i}+\epsilon_{i t}
$$

where $R_{i t}$ denotes the difference between the Treasury yield and the yield on bonds issued by each state. East ${ }_{i t}$, and $X_{i t}$ are the share of "left political party" and economic 
covariates of state $i$ in fiscal year $t$, respectively. Among various economic variables, we control for the three economic variables that turn out to have the most significant effect on dependent variable : unemployment rate, the overall size of a state's economy measured by real GDP, and state budget deficit to GDP. $S_{i}$ is a set of unobservable that is specific to state i but time invariant. As $S_{i}$ is unobservable, we first-differentiate Equation (4) in order to get rid of $S_{i}$ and have the following equation:

$$
\Delta R_{i t}=\alpha+\beta_{1} \text { Defshock } \text { sit }+\beta_{2} \Delta\left(\text { Defshock }_{i t} \text { East }_{i t}\right)+\beta_{3} \Delta X_{i t}+\Delta \epsilon_{i t}
$$

where $\Delta$ denotes time-difference operator. The dependent variable, $R_{i t}$, is the difference between the maximum and minimum yield spread of state $i$ in a given year $t$. To explore the robustness of our findings, we also use an yield spread of state $i$ averaged for a given year $t$ or for December of each year $t$ and we find that our result does not depend on the various measures of our dependent variable.

Table 1: Average State Deficit Shocks

\begin{tabular}{|c|c|c|c|c|}
\hline $\begin{array}{c}\text { Fiscal } \\
\text { Year }\end{array}$ & \multicolumn{2}{|c|}{$\begin{array}{c}\text { Unexpected } \\
\text { increase in } \\
\text { Budget deficit }\end{array}$} & \multicolumn{2}{c|}{$\begin{array}{r}\text { Unexpected } \\
\text { increase in } \\
\text { Net Debt }\end{array}$} \\
\hline & $\begin{array}{c}\text { in Million } \\
\text { EUR }\end{array}$ & $\begin{array}{r}\text { in \% of } \\
\text { Exp. Budget }\end{array}$ & $\begin{array}{r}\text { in Million } \\
\text { EUR }\end{array}$ & $\begin{array}{r}\text { in \% of } \\
\text { Exp. Debt }\end{array}$ \\
\hline 2005 & -218.7 & 1.09 & 183.3 & 1.11 \\
\hline 2006 & 95.2 & 0.39 & 614.5 & 5.36 \\
\hline 2007 & -200.6 & 1.14 & 461.1 & 2.86 \\
\hline 2008 & 369.1 & 1.49 & 858.3 & 3.27 \\
\hline 2009 & 122.3 & 1.02 & 122.5 & 1.16 \\
\hline
\end{tabular}

\section{DATA}

A full list of variables and their sources is given in Appendix A. As not all data is readily available from our main sources, Datastream and German federal and sate statistical offices, this section also provides an overview over the methods of data set composure.

To determine the dependent variable of our analysis, we calculate time series by using bond data provided by Datastream for the period of 01/01/2006 - 12/31/2010. Data is available for 15 out of the 16 German states with the exception of Bremen. We further include observations on bonds jointly issued by different states (Gemeinschaft der Länder, Jumbo bonds). Like Schulz \& Wolff (2009) we restrict our sample to straight bonds denominated in Euros. More than 500 bonds remain in the sample.

When computing daily spreads we note that not all bonds issued on state level can be matched with government bonds that are equivalent in structure and residual maturity. 
We solve this issue by using data on spreads of state bond yields over equivalent benchmark redemption yields directly provided by Datastream.

We cluster our data into four groups according to years of residual maturity of the respective bond at the date of yield observation. Within each cluster we average yield spreads of bonds issued by identical states over respective government benchmark redemption yields.

We now can calculate average spreads for each state within each of the four groups. We observe that within each of the four groups, average values of bond spreads differ across states. Like Schulz \& Wolff (2009) we observe that average spreads of Jumbo bonds are among the lowest in the sample. We interpret the fact that this finding is consistent with results of other researchers as confirmation of our procedure. We focus our analysis on maturity class 2 as this is the sample with the largest number of bonds.

Table 2: Descriptive statistics: state bond spreads over government benchmarks

\begin{tabular}{|l|c|c|c|c|}
\hline & $\begin{array}{c}\text { Maturity } \\
\text { Class I }\end{array}$ & $\begin{array}{c}\text { Maturity } \\
\text { Class II }\end{array}$ & $\begin{array}{c}\text { Maturity } \\
\text { Class III }\end{array}$ & $\begin{array}{c}\text { Maturity } \\
\text { Class IV }\end{array}$ \\
\hline Time to Maturity & 0-4 years & $4-7$ years & 7 -11 years & $>$ 11 years \\
\hline Number of bonds (N) & 281 & 390 & 176 & 26 \\
\hline Mean* & 69.58 & 49.23 & 41.09 & 52.87 \\
\hline Standard Deviation* & 50.55 & 34.04 & 22.19 & 46.68 \\
\hline Min* & -179.40 & -32.10 & -3.19 & -75.20 \\
\hline Max* & 350.95 & 181.15 & 134.75 & 1325.60 \\
\hline
\end{tabular}

*Spreads in basis points

In our calculations of unexpected deficit shocks and changes in revenues from taxes and administration we refer to data on projected and realized revenues and expenditures as published in the budget plans of the state parliaments and the audit offices of German states. For calibrating our economic and fiscal control variables we use employment data that we directly obtain from the German statistical office (2007 - 2010, table 3) for the period of 2006 - 2009. To control for the potential impact of relative size for the same period we rely on GDP data available from the German statistical office $(2007$ - 2010). We further control for the relative size of budget deficits in terms of GDP, calculating budget deficits as differences between state revenues and expenditures (German statistical office, 2007-2009, Table 23; ibid., 2010, Table 24.21). We also control for differences in productivity by calculating GDP per capita ratios relying on data from statistical yearbooks on state level GDP (ibid., table 4) and state population (ibid., 2007 - 2010, table 2). We account for institutional arrangements of German fiscal federalism by computing horizontal transfers (ibid., table 23.1.4) and vertical transfers (ibid.) for the period of 2006 - 2009 that we include into our regressions.

When testing for the relevance of party-identity for state specific risk perceptions, we apply different approaches. The German party landscape is dominated by five parties: 
The CDU (the Christian democratic party), the FDP (the liberal party), the SPD (the social democratic party), and the Green party. "With German reunification ... a far left wing party, the PDS (Socialist party), which succeeded the former SED that ruled the GDR, won considerable votes in local ... as well as in all state parliaments of the Neue Laender [states in the territory of the former GDR]" (Seitz 2000, p.190). In 2007, the PDS formed together with the Wahlalternative Arbeit und soziale Gerechtigkeit (Labour and Social Justice - The Electoral Alternative) a new party called "Die Linke" (The Left). Die Linke entered state parliaments in Bremen (2007), Hesse (2008) and Lower Saxony (2008). Together with its seats in the parliaments of the five states that are on the territory of the former GDR and Berlin, Die Linke has since then been present in nine out of 16 German state parliaments.

We test the "left party-hypothesis" (e.g. Alesina, Ardagna, and Trebbi (2006)) by using data on the fraction of legislative seats held by the SPD and Die Linke in state parliaments using information published in the statistical yearbooks of 2007 - 2010. For our tests of the relevance of other institutional factors such as assumed party solidarity across federal and state levels we construct a binary variable. This variable captures party identity of the head of state government as being either identical to head of federal government (1), or not (0).

To be able to differentiate between residual effects due to economic and institutional characteristics and factors that are correlated to differences in recent history and/or geographic situation of German states, that may influence investors' sentiments, we introduce a dummy variable for bonds being either issued by an Eastern German state (1) or not (0). We aim at separating effects due to "Easterness" from other effects that are specific to states in the former territory GDR, i.e. parliamentary and governmental relevance of parties at the far left (Die Linke/PDS), and differences in electoral participation. We account for differences in political participation by computing voter turn-outs as recorded in the statistical yearbooks $(2007-2010)$.

\section{Liquidity measure}

German subnational bond markets are characterized by liquidty differences that lead to varying transactions costs and thus may impact spreads of state bonds over government equivalent benchmarks (Schulz \& Wolff (2009, p.68). In the absence of a theory, "a definition of illiquidity and its quantifications remain imprecise" (Bao, Pan, Wang, 2008, p. 8). In order to account for differences in liquidity we introduce a control variable relying on the proxy proposed by Schulz \& Wolff (2009). Schulz \& Wolff (2009, p.68) reason that

"[t]he law of one price states, that the bonds of one Land outstanding at a point in time (after adjusting for the term spread as we pool bonds into maturity classes) should have identical yields. Assuming the absence of arbitrage opportunities, the remaining yield differences are a sign of differing liquidity. 
Otherwise, traders would be able to exploit the yield differential thus equalling the yields of the respective bonds."

Following the approach of Schulz \& Wolff (2009, p.68) we introduce a liquidity measure into our considerations that "is related to Longstaff (2004) as he compares the spread between two bonds with equal credit risk (US Treasuries and bonds of Refco, which enjoys a federal guarantee)". Like Schulz \& Wolff (2009, p.68) "we compare the yield dispersion of two or more bonds which have the same credit risk," as issuing states are identical. We do so by computing daily standard deviations of yield spreads of state bonds over government bechnmark equivalents.

In analogy to our calibrations of state specific average spreads we rely on daily information provided by Datastream on "those bonds used to compute the respective average" spread curves in our model (Schulz \& Wolff, 2009). We obtain values for each state within each of the four different maturity classes. Analoguous to our focus on daily bond spreads we focus on data in maturity class II in context of our further analysis.

\section{FINDINGS}

The main empirical results are presented in Table 3 in which we use state bond's spread as a proxy for states' risk. The first column is a regression of change in spread on a number of economic variables: changes in GDP, unemployment rate, vertical transfer from federal government, and horizontal transfer from other states, and liquidity. As expected, size of the economy measured by GDP and unemployment rate have a positive association with an increase in state's risk, whereas transfer has a little but negative association. This result is consistent with studies that identify the size of the economy as the most important determinant of state's risk in the U.S. during the financial crisis.

The second column reports that budget deficit shock has a positive and significant association with a state' risk. An unexpected increase in budget deficit by a one billion EUR is associated with additional 16 percentage points increase in state bond spread. However, this estimate rises to 50 percentage points for "Eastern States". In other words, an unexpected budget deficit has had a greater negative impacts on a state's risk in "Eastern states". This result becomes even more significant when we control for other political variables.

In column 3, we control for the party identity of the Head of state government by including a dummy variable with a value 1 if the party of the Head of state government is the same as that of Chancellor and 0 otherwise. We also control for the interaction between the party identity of the Head of state government and budget deficit shock to have a more flexible functional form. As we see in column 3, the estimated impacts slightly increase.

In columns (4) and (5), we also present a model with the share of SPD in state legislature as a control variable. In order to have a clearer interpretation of the model, we take an 
average share of SPD as a control. Taking average of SPD party share in the model is justified as there were little change in the share in our data set as it covers a relatively short period of time. In addition to SPD, we also include other political states in order to see whether the results in columns (2)-(5) are robust to different specifications.

We found that those added political parties did not have significant impact on the model and the results in (2)-(5) remains significant.

\section{Easterness vs. Die Linke}

Taken altogether, estimates in Table 3 show that Eastern states had a higher increase in borrowing costs in response to a budget shock even after we control for key economic and political variables.

Then, why do Eastern states have a higher increase in risk in response to a negative economic shock? There might be many different explanations for this finding, but in this paper we try to focus on whether we find evidence that the share of the left party (Die Linke) is associated with the result presented in Table 3. The left party (Die Linke) is more influential in Eastern states. Thus it might be that the policies proposed by the left party or simply their presences in either the government or legislature are correlated with the observed higher borrowing costs. To test this argument, we estimate Equation (5) with the left party's control of the government and legislature as treatment variables in place of a dummy variable indicating an Eastern state.

Table 4 presents the result. Column (1) uses a dummy variable indicating whether left party (Die Linke) participates in the government or not, and column (2) uses the share of left party (Die Linke) in the state legislature as the treatment variable. We see that both estimates are statistically significant; in other words, a higher left party share in either the government or legislature is associated with a higher increase in borrowing costs in response to a negative budget shock. However, the results in column (1) and (2) are not robust to different specifications. For example, Eastern states had a lower average voter turnout during 2006-10, and we find that a lower democratic participation measured by voter turnout is highly associated with a higher borrowing costs in response to a negative budget shock, as presented in column (3).

Furthermore, the coefficients in column (1) and (2), which measures the impact of a change in the left party, are no longer statistically significant when we add a democratic participation as a control in column (4). These evidences suggest that there might be factors other than the share of the left party, which exposes Eastern states to a higher risk. 


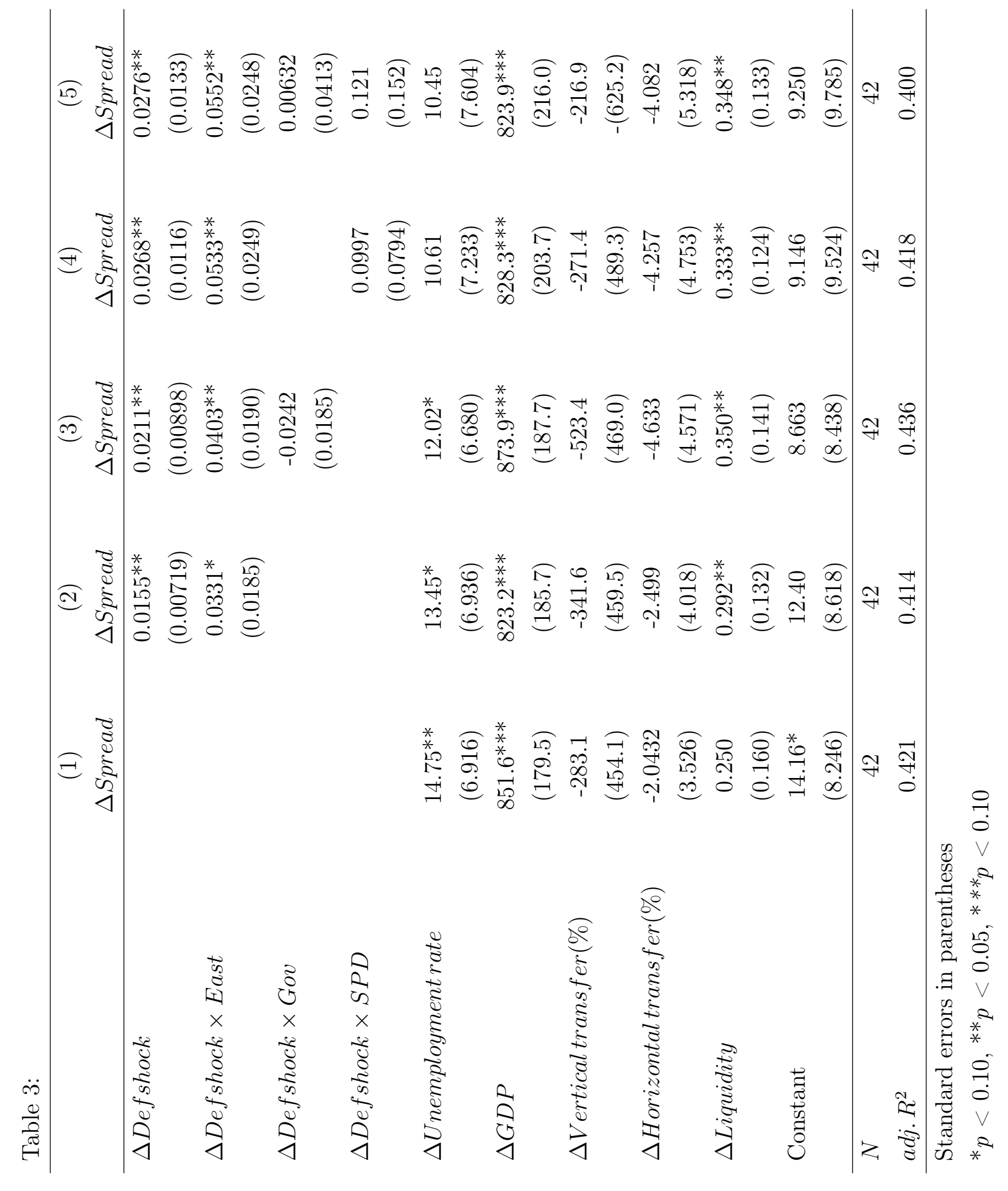




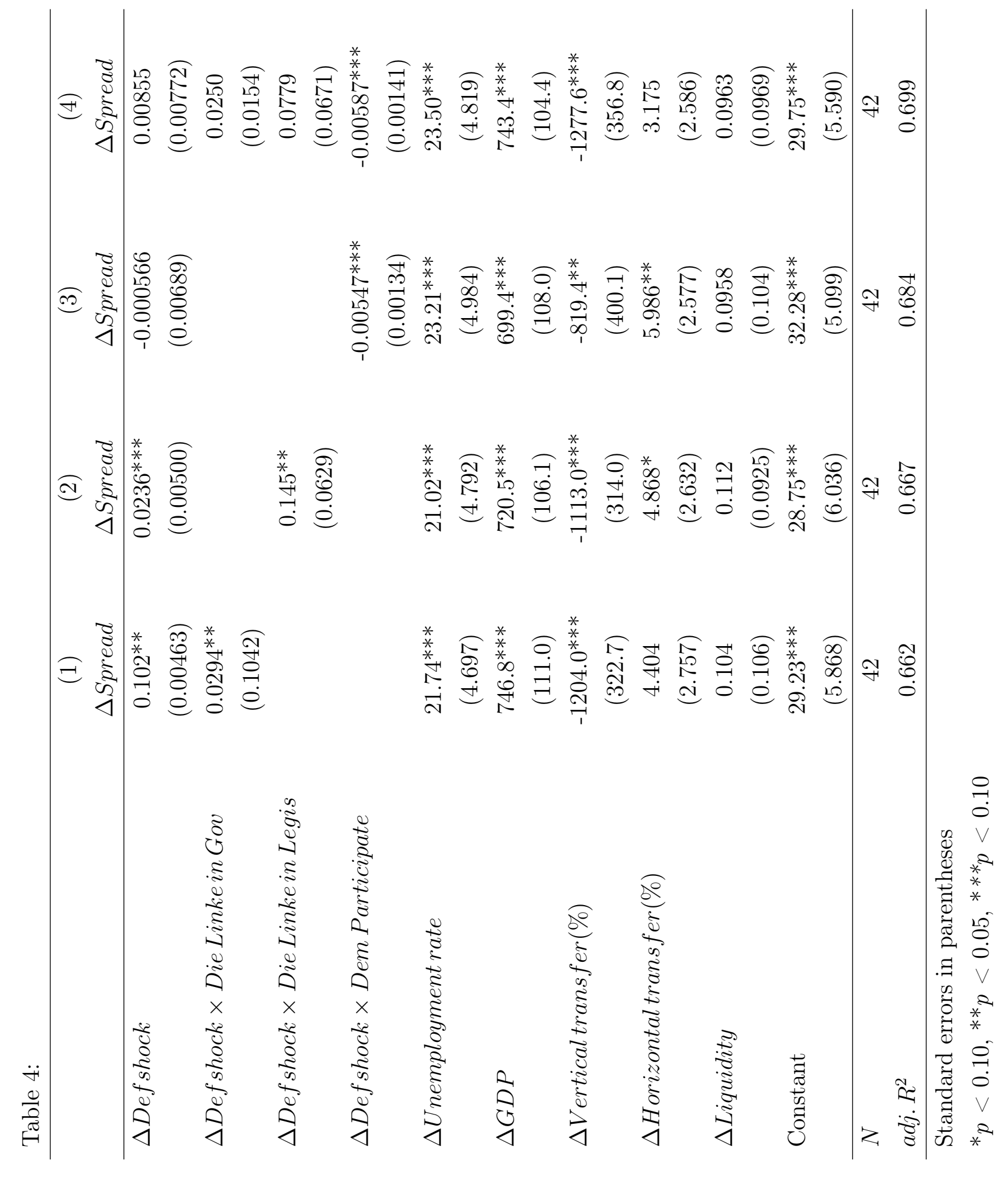




\section{CONCLUSIONS AND FUTURE DIRECTIONS}

Our investigation confirms existing results on the economic effects of state political institutions. In analogy to previous studies we found that both the presence of various fiscal rules as well as political institutions affect the average borrowing costs of states within a federal framework. Moreover, this paper presents new evidence on three issues.

First, by studying how the German state bond market reacted to unexpected deficit shcoks we present clear evidence of a link between state finances and changes in the required yield on general obligation debt. This finding adds to ongoing discussions on the question in how far bond markets perceive of German states as entities that can default. It implies that during the financial crisis bond markets were discounting state specific factors when evaluating state default risks. In a world of unconditional and universal bailout guarantees state specific factors should not impact state default risks. We hence interpret our finding as reflection of investor assumptions according to which state bailouts by the federal government would be carried out at non-zero costs.

Second, we were surprised to observe that Eastern states displayed higher increases in borrowing costs in response to budget shocks. This observation holds even after we controlled for key economic and political variables. While some studies hold that capital markets discounted "Easterness" as risk factor during the 1990s (cf. above) we are not able to reject the hypothesis that there may be other factors that explain our observations. For example, systematic differences in yields of Eastern and Western German states could also be explained by variances in parliamentory fractions held by far left parties such as "Die Linke / PDS". In this case our observation could be explained by partisan approaches that assume investors to differentiate between various parties with regard to fiscal prudence and bailout policies. Similar reasoning applies with regard to differences in electoral participations that are lower in the East than in the West. Hence, further analysis is necessary to isolate additional factors so as to be able to better explain this part of our observations. This analysis should most likely contain explorative elements testing for factors that we might have overseen in our present analysis.

Third, we find that fiscal institutions such as vertical and horizontal transfers matter. As the regression tables show, we have to be careful in the interpretations of our results before we can draw certain conclusions. States that are net recipients of fiscal transfers seem to face lower borrowing costs than states that do not receive those benefits. With regard to vertical transfers a potential explanation might be that markets assume that it is easier for states that already receive transfers to file for additional funds than it is for other states to forsake their status of independence and to tap federal resources for the first time. In case of horizontal transfers ambiguities prevail. On the one hand, bond markets may assume states that are already receiving transfers from other states to be in a better position to negotiate additional funds in case of distress than states that are net payers of vertical transfers. On the other hand, markets may discount obligations of net paying states within the context of the German transfer system as additional liabilities and burden on the fiscal independence of these states. Our findings open up questions 
on the role of transfers in context of costs and benefits of fiscal transfer unions. These questions are relevant beyond the specific case of Germany.

Some caveats remain. We will discuss four of them that we believe to be most relevant for our results. Due to analogies between our approach and the procedure suggested by Poterba \& Rueben (2001) the caveats are partially identical with those suggested by the latter. They comprise of questions with regard to the "rationality of budget forecasts of both expenditures and revenues" (ibid.). For, "[t]here may be political influences on these forecasts, and the extent to which these forecasts make use of all publicly available information that could bear on the prediction is unclear" (ibid). Hence, endogeneity problems persist. Furthermore, as Schulz \& Wolff (2009) demonstrate liquidity differences play an important role for yield performances within the context German state bond markets. While we replicate the approach of the former so as to account for these differences our observations are still based on a liquidity proxy. In lack of better alternative we cannot fully erase inexactitudes in our data. Another issue is the problem of state guarantees. In retrospect we can say that state governments faced severe burdens due to their obligations to bail out state owned banks that went into distress in context with the global enfolding of the financial crisis. Ex-post observations show that state owned banks placd heavy burdens onto state budgets. But could investors foresee this from an ex-ante perspective? Many of the banking activities that led to the financial turmoil were off-balance operations and banks differed in how the recorded and communicated those activities to the public. So it is questionable in how far and at what time state bond markets did know about those activities and their consequences. Finally, imprecisions also stem from the fact that our equations have only 15 time-series observations due to the number of German states that issue bonds (cf. Poterba \& Rueben, 2001).

What are the prospects that limits in our research can be overcome in future investigations? In order to overcome endogeneity issues it would be necessary to find out in how far budget forecasts are truly of political nature. It would thus be necessary to look for evidence that would show that governments systematically mis-predict the future before we can make further suggestions how to alter the variable Defshock. With regard to liquidity issues we note that it is yet unclear how the recently introduced debt brake that forbids German states to take out new loans after 2020 will affect future bond issuances of the latter. We hence do not know if German state bond markets that only have been evolving since the 1990s will become more liquid over time (thus offering a natural solution to the problem of liquidity differences) or whether they will dry out. In the latter case, revisions of sampling strategies (e.g. by introducing different sub-sample categories) should be considered carefully due the fact that less liquid market would most likely imply thinner data on which observations can be based. As to the issue of state owned banks and other state guarantees researchers could exploit their ex post situation looking in form of an event study bearing in mind that not all information that is available as of today has been available to markets between 2008 - 2010. To overcome the limited number of time series observations future research could add observations on analogous debt instruments that bear state guarantees. 


\section{References}

1. Alesina, A. (2010). "Fiscal Adjustments. Lessons from Recent History" Unpublished Paper.

2. Alesina, A. Perotti, R., \& Tavares, J. (1998). "The Political Economy of Fiscal Adjustments", Brookings Papers on Economic Activity, 1, pp. 197-248.

3. Alesina, A., Ardagna, S. (1998). "Tales of Fiscal Adjustment." Economic Policy, 13, pp.487-545.

4. Alesina, A., Ardagna, S. \& Trebbi, F. (2006). "Who Adjusts and When? On the Political Economy of Reforms", Harvard Institute of Economic Research Working Papers 2108, Harvard - Institute of Economic Research.

5. Alesina, A., De Broeck, M., Prati, A, \& Tabellini, G. (1992). "Default Risk on Government Debt in OECD Countries". Economic Policy, 15, pp.427-451.

6. Alesina, A., Perotti, R. (1995). "Fiscal Expansions and Fiscal Adjustments in OECD Countries". Economic Policy 21, pp. 205-248.

7. Alesina, A., Perotti, R. (1996). "Budget Deficits and Budget Institutions". National Bureau of Economic Research Working Paper 5556.

8. Alt, J., Lowry, R. (1994). "Divided Government, Fiscal Institutions, and Budget Deficits: Evidence from the States", American Political Science Review, 88, pp. 811-828.

9. Ardagna, S. (2004). "Fiscal Stabilizations: When Do They Work and Why." European Economic Review 48, pp.1047-74.

10. Baldacci, E., Gupta, S. \& Mati, A. (2008). "Is It (Still) Mostly Fiscal? Determinants of Sovereign Spreads in Emerging Markets", IMF Working Paper 08/259, International Monetary Fund.

11. Bayerischer Oberster Rechnungshof $(2007$ - 2010). Jahresbericht, laufender Jahrgang (annual reports), München.

12. Bayoumi, T., Goldstein, M., \& Woglom G. (1995). "Do Credit Markets Disciplline Sovereign Borrowers? Evidence from the U.p. States". Journal of Money, Credit, and Banking 27 (4), pp.1046-1059.

13. Bernoth, K., von Hagen, J., Schuknecht, L. (2004). "Sovereign Risk Premia in the European Government Bond Market". ECB Working Paper 369. Bernoth, K., Wolff, G.B. (2008). "Fool the Markets? Creative Accounting, Fiscal Transparency and Sovereign Risk Premia". Scottish Journal of Political Economy 55, pp.465-487.

14. Booth, L., Georgopoulos, G. \& Hejaz, W. (2007), "What Drives Provincial-Canada Yield Spreads? Canadian Journal of Economics, 40, pp. 1008-1032.

15. Buti, M., Van den Noord, P. (2003). "Discretionary Fiscal Policy and Elections: The Experience of the Early Years of EMU". OECD Economics Department Working Paper, ECO/WKP(2003)5.

16. Capeci, J. (1991). Credit Risk, Credit Ratings, and Municipal Bond Yields: A Panel Study. National Tax Journal, 44(1), pp. 41-56.

17. Capeci, J. (1994). "Local Fiscal Policies, Default Risk, and Municipal Borrowing Costs". Journal of Public Economics 53, pp.73-89. Carlin, W., 
18. Richthofen, P. (1995). "Finance, Economic Development and the Transition: The East German Case", Wissenschaftszentrum Berlin für Sozialforschung Discussion Paper FSI95-301.

19. Copeland, L., Jones, S.-A. (2001). "Default Probabilities of European Sovereign Debt: Marketbased estimates", Applied Economic Letters 8, pp. 321-324.

20. Deutsche Bank Research (2011). "Finanzen der Bundesländer. Im Schatten des Bundes, Aktuelle Themen 513, www.dbresearch.de (as of 2011-12-05).

21. Eichengreen, B., Moody, A. (2000). "What Explains Changing Spreads on Emerging Market Debt" in: Edwards, S. (ed.), Capital Flows and the Emerging Economies: Theory, Evidence, and Controversies, National Bureau of Economic Research Conference Reports Series, University of Chicago Press, Chicago and London, pp. 107-234.

22. Esters, C., Strasser, A. (2001). "Ratings der Bundesländer: Zunehmende Bondemissionen lenken Aufmerksamkeit auf Kreditqualität". Standard \& Poor's.

23. Fox, K.-P. (2002). "Das Rating von Ländern bei der Kreditaufnahme ist verzichtbar". Wirtschaftsdienst 2002 (6), pp. 357-364.

24. Freie und Hansestadt Hamburg (2005). Haushaltsrechnung 2005. Kurzfassung. Anlage zur Bürgerschaftsmitteilung 18/5306, Hamburg.

25. Freie und Hansestadt Hamburg (2006). Haushaltsrechnung 2006. Kurzfassung. Anlage zur Bürgerschaftsmitteilung 18/7294, Hamburg.

26. Freie und Hansestadt Hamburg (2007). Haushaltsrechnung 200\%. Kurzfassung. Anlage zur Bürgerschaftsmitteilung 19/1577, Hamburg.

27. Freie und Hansestadt Hamburg (2008). Haushaltsrechnung 2008. Kurzfassung. Anlage zur Bürgerschaftsmitteilung 19/4580, Hamburg.

28. Grötecke, F., Mause, K. (2009). "Die deutsche 'Schuldenbremse': Ein wirksames Instrument zur Vermeidung eines Bailout?", Zeitschrift für Wirtschaftspolitik 58 (3), pp. 309-335.

29. Hallerberg, M., Wolff, G.B.(2008). "Fiscal Institutions, Fiscal Policy and Sovereign Risk Premia in EMU". Public Choice 136, pp.379-396.

30. Heppke-Falk, K., \& Wolff, G. B. (2008). "Moral Hazard and Bail-out in Fiscal Federations: Evidence for the German Länder". Kyklos, 61(3), 425-446.

31. Hessischer Rechnungshof (2006). Bemerkungen 2005 zur Haushalts- und Wirtschaftsführung des Landes Hessen, Hessischer Landtag, Drucksache 16/5550, Darmstadt.

32. Hessischer Rechnungshof (2007). Bemerkungen 2006 zur Haushalts- und Wirtschaftsführung des Landes Hessen, Hessischer Landtag, Drucksache 16/7156, Darmstadt.

33. Hessischer Rechnungshof (2008). Bemerkungen 2007 zur Haushalts- und Wirtschaftsführung des Landes Hessen, Hessischer Landtag, Drucksache 17/25, Darmstadt.

34. Hessischer Rechnungshof (2009). Bemerkungen 2008 zur Haushalts- und Wirtschaftsführung des Landes Hessen, Hessischer Landtag, Drucksache 18/337, Darmstadt.

35. Hessischer Rechnungshof (2010). Bemerkungen 2009 zur Haushalts- und Wirtschaftsführung des Landes Hessen, Hessischer Landtag, Drucksache 18/2195, Darmstadt. 
36. Hibbs, D. (1977). "Political Parties and Macroeconomic Policy", American Political Science Review 71 , pp. $467-487$.

37. Hibbs, D. (1987). The American Political Economy, Harvard University Press: Cambridge, MA.

38. Hunt, J. (2000). "Why Do People Still Live in East Germany?" National Bureau of Economic Research Working Paper 7564.

39. Iara, A., Wolff, G.B. (2010)."Rules and Risk in the Euro Area: Does Rules-Based National Fiscal Governance Contain Sovereign Bond Spreads?", European Economy - Economic Papers 433, European Commission / Directorate General Economic and Monetary Affairs.

40. Johnson, C., Kriz, K., (2005). "Fiscal Institutions, Credit Ratings, and Borrowing Costs". Public Budgeting and Finance 25 (1), pp.84-103.

41. Land Sachsen-Anhalt (2005). Haushaltsrechnung des Landes Sachsen-Anhalt für das Haushaltsjahr 2005. Gesamtrechnung, Magdeburg.

42. Land Schleswig-Holstein (2006 - 2010). Haushaltsrechnung und Vermögensübersicht für das Haushaltsjahr, laufender Jahrgang (annual reports), Kiel.

43. Landesrechnungshof Brandenburg (2007 - 2010). Jahresbericht, laufender Jahrgang (annual reports), Potsdam.

44. Landesrechnungshof Mecklenburg Vorpommern (2005). Jahresbericht 2005, Schwerin.

45. Landesrechnungshof Mecklenburg Vorpommern (2006). Jahresbericht des Landesrechnungshofes 2006 (Teil 2) mit Bemerkungen zur Haushaltsrechnung des Landes 2004, Schwerin.

46. Landtag Mecklenburg-Vorpommern, Drucksache 5/93, Schwerin.

47. Landesrechnungshof Mecklenburg Vorpommern (2007). Jahresbericht des Landesrechnungshofes 200\%. (Teil 2), Schwerin.

48. Landesfinanzbericht 2007, Landtag Mecklenburg-Vorpommern, Drucksache 5/1040, Schwerin.

49. Landesrechnungshof Mecklenburg Vorpommern (2008). Jahresbericht des Landesrechnungshofes 2008. (Teil 1) Landesfinanzbericht 2008, Schwerin.

50. Landtag Mecklenburg-Vorpommern, Drucksache 5/1660, Schwerin.

51. Landesrechnungshof Mecklenburg Vorpommern (2009). Jahresbericht des Landesrechnungshofes 2009. (Teil 1) Landesfinanzbericht 2009, Schwerin.

52. Landtag Mecklenburg-Vorpommern, Drucksache 5/2661, Schwerin.

53. Landesrechnungshof Nordrhein-Westfalen (2007 - 2010). Jahresbericht des Landesrechnungshofs Nordrhein-Westfalen über das Ergebnis der Prüfungen im Geschäftsjahr, laufender Jahrgang (annual reports), Düsseldorf.

54. Landesrechnungshof Sachsen-Anhalt (2005-2010). Jahresbericht, laufendes Jahr (annual reports), Magdeburg.

55. Landtag Schleswig Holstein (2006), Bericht zur Landeshaushaltsrechnung, Abschluss der Haushaltsrechnung 2005, Kiel.

56. Laulajainen, R. (1999). "Subnational Credit Ratings - Penetrating the Cultural Haze". Geojournal 47 (4), pp.501-510. 
57. Lemmen, J. (1999). "Managing Government Default Risks in Federal States". Financial Markets Group Special Paper, London School of Economics.

58. Liu, L., Tan, K.S. (2008). "Creditworthiness Assessment of Subnational Governments". World Bank, Washington DC.

59. Longstaff, F. (2004). "The Flight-to-Liquidy Premium in U.S. Treasury Bond Prices". Journal of Business 77, pp. 511-526.

60. Lowry, R., Alt, J. (1997). "A Visible Hand? Bond Markets, Political Parties, Balanced Budget Laws, and State Government Debt". Mimeo, Harvard University Department of Government.

61. Nadler, D., Hong, S. (2011). "Political and Institutional Determinants of Tax-Exempt Bond Yields". Working Paper, Harvard Kennedy School of Government, www.hks.harvard.edu/newsevents/news/press-releases/pepg-nadler-hong-study (as of 2011-12-12)

62. Neuberger, D. (1999). Regionalökonomie und Finanzierung kleiner und mittelständischer Unternehmen: Ansätze zur Erklärung eines Ost-West-Gefälles. Thünen Series of Applied Economic Theory Working Paper 24, Universität Rostock, Wirtschafts- und Sozialwissenschaftliche Fakultät, Institut für Volkswirtschaftslehre.

63. Niedersächsischer Landesrechnungshof (2007 - 2010). Jahresbericht des Niedersächsischen Landesrechnungshofs. Laufendes Jahr. Zur Haushalts- und Wirtschaftsführung. Bemerkungen und Denkschrift des Landes Niedersachsen für das Haushaltsjahr, laufender Jahrgang (annual reports), Hildesheim.

64. Nord/LB (2010). "Public Issuers: Deutsche Bundesländer". Economics and Strategy 2010-04-30, https://www.nordlb.de (as of 2011-12-05).

65. Poterba, J., \& Rueben, p. K., (2001). "Fiscal News, State Budget Rules, and Tax-Exempt Bond Yields", Journal of Urban Economics 50, pp.537-562.

66. Poterba, J., Rueben, K. (1999). State Fiscal Institutions and the U.S. Municipal Bond Market, in: Poterba, J., von Hagen, J. (eds.), "Fiscal Institutions and Fiscal Performance", University of Chicago Press, Chicago.

67. Rechnungshof Baden-Württemberg (2010). Denkschrift 2010 zur Haushalts- und Wirtschaftsführung des Landes Baden-Württemberg, Stuttgart.

68. Rechnungshof Berlin (2007 - 2010). Jahresbericht, laufender Jahrgang (annual report), Berlin.

69. Rechnungshof des Freistaates Sachsen (2006 - 2010). Jahresbericht, laufender Jahrgang (annual report), Leipzig.

70. Rechnungshof des Saarlandes (2007-2010). Jahresbericht über Haushalts- und Wirtschaftsführung des Saarlandes mit Bemerkungen zur Landeshaushaltsrechnung, laufender Jahrgang (annual report), Saarbrücken.

71. Rechnungshof Rheinland-Pfalz (2007 - 2010). Jahresbericht, laufender Jahrgang (annual report), Speyer.

72. Rodden, J. (2006). Hamilton's Paradox: The Promise and Peril of Fiscal Federalism. Cambridge University Press, Cambridge.

73. Roubini, N., Sachs, J. (1989). "Political and Economic Determinants of Budget Deficits in the Industrial Democracies." European Economic Review, Vol. 33, pp.903-33. 
74. Schuknecht, L., von Hagen, J., \& Wolswijk, G. (2009). "Government Risk Premiums in the Bond Market: EMU and Canada". European Journal of Political Economy, 25(3), pp.371-384

75. Schulz, A., \& Wolff, G. B. (2009). "The German Sub-national Government Bond Market: Structure, Determinants of Yield spreads and Berlin's Gorgone Bail-out. Jahrbucher für Nationalokonomie und Statistik, 229(1), pp.61-83.

76. Seitz, H. (2000). "Fiscal Policy, Deficits and Politics of Subnational Governments: The Case of the German Laender". Public Choice 102, pp. 183-218.

77. Seitz, H. (2006). "Zur Quantifizierung des 'Korb 2' im Rahmen des Solidarpakts II". Working Paper, www.tu-dresden.de (as of 2011-11-05).

78. Sinn, G., Sinn, H.-W. (2009). "Muffled jumpstart", www.VoxEU.org (as of 2011-12-05).

79. Thüringer Rechnungshof (2007 - 2010). Jahresbericht, laufender Jahrgang (annual report), Rudolstadt. 


\section{Appendix (A): Overview of Reported Variables}

\begin{tabular}{|c|c|c|c|c|}
\hline Variable & Data & Measure & Source & Calculation \\
\hline$\Delta$ Spread & $\begin{array}{l}\text { Difference between state bond yields } \\
\text { and government benchmark equivalent, daily spreads }\end{array}$ & $\begin{array}{l}\text { basis } \\
\text { points }\end{array}$ & Datastream & Datastream \\
\hline$\Delta$ DefShock & $\begin{array}{l}\text { Difference between expected } \\
\text { and realized budget deficits }\end{array}$ & EUR mill. & $\begin{array}{l}\text { State audits } \\
\text { / budgets }\end{array}$ & Own calculation \\
\hline $\begin{array}{l}\Delta \text { Unemployment } \\
\text { rate }\end{array}$ & $\begin{array}{l}\text { Registered unemployed as fraction of workforce, } \\
\text { annual data }\end{array}$ & $\%$ & Stat. yearbooks & Own caclulation \\
\hline$\triangle G D P$ & GDP per capita, annual data & EUR K & Stat. yearbooks & Own calculations \\
\hline $\begin{array}{l}\Delta \text { Horizontal } \\
\text { transfer }\end{array}$ & $\begin{array}{l}\text { Transfers from other states in } \% \text { of state revenues, } \\
\text { annual data }\end{array}$ & $\%$ & Stat. yearbooks & Own calculation \\
\hline $\begin{array}{l}\Delta \text { Vertical } \\
\text { transfer }\end{array}$ & $\begin{array}{l}\text { transfers from fed. gov. in \% of state revenues } \\
\text { annual data }\end{array}$ & $\%$ & Stat. yearbooks & Own calculation \\
\hline East & $\begin{array}{l}\text { If state is on territory of former } \\
\text { GDR (exlcuding Berlin) }\end{array}$ & binary & $\begin{array}{l}\text { Länderneuglie- } \\
\text { derungsgesetz }\end{array}$ & NA \\
\hline Gov & $\begin{array}{l}\text { if party identity of head of state identical to par- } \\
\text { ty identity of fed. chancelor identical to CDU }\end{array}$ & binary & Stat. yearbooks & NA \\
\hline$S P D$ & Fraction of state parliament seats held by SPD & $\%$ & Stat. yearbooks & Own calculation \\
\hline $\begin{array}{l}\text { Die Linke } \\
\text { in Gov }\end{array}$ & Fraction of state gov. seats held by extreme left party & $\%$ & Stat. yearbooks & Own calculation \\
\hline $\begin{array}{l}\text { Die Linke } \\
\text { in Legis }\end{array}$ & $\begin{array}{l}\text { Fraction of state parliament seats held by extreme } \\
\qquad \text { left party }\end{array}$ & $\%$ & Stat. yearbooks & Own caclulation \\
\hline DemParticipate & Voter turn up in last state elections & $\%$ & Stat. yearbooks & Stat. yearbooks \\
\hline$\Delta$ Liquidity & $\begin{array}{l}\text { standard deviations of yield spreads of bonds issued } \\
\text { by identical states within identical maturity class }\end{array}$ & $\begin{array}{l}\text { basis } \\
\text { points }\end{array}$ & Datastream & Own caculation \\
\hline
\end{tabular}




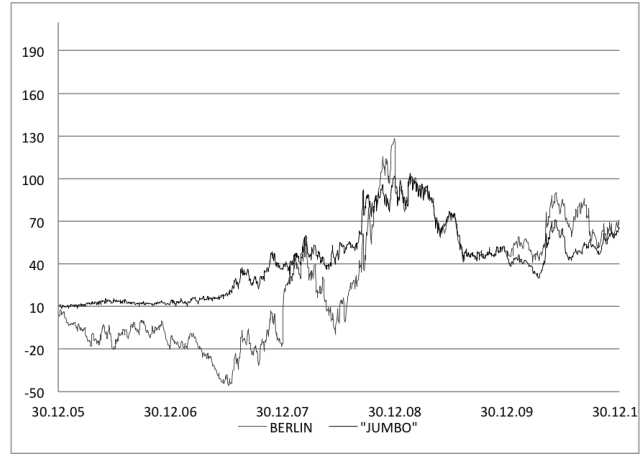

Figure 1: Berlin

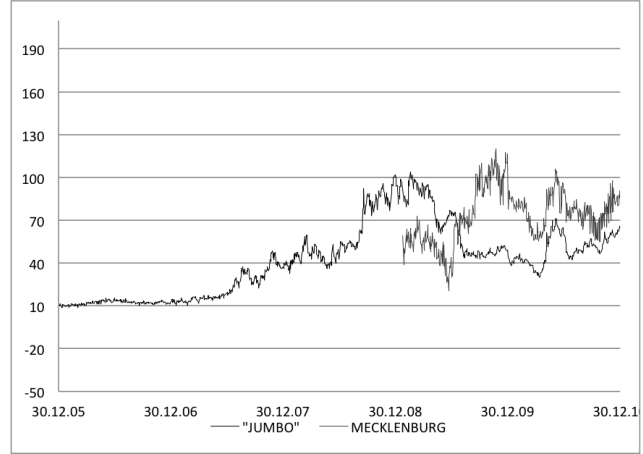

Figure 3: Mecklenburg

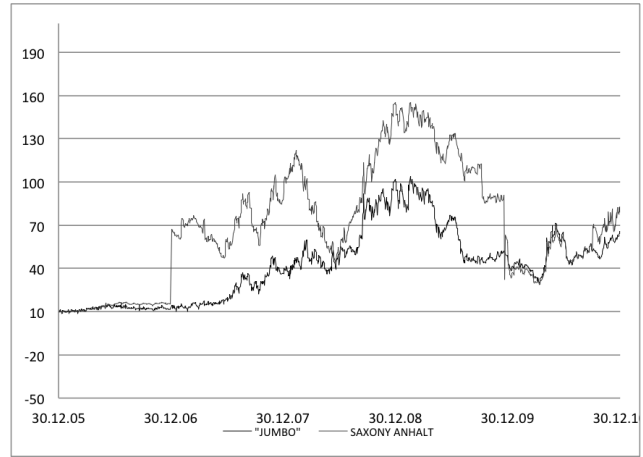

Figure 5: Saxony Anhalt

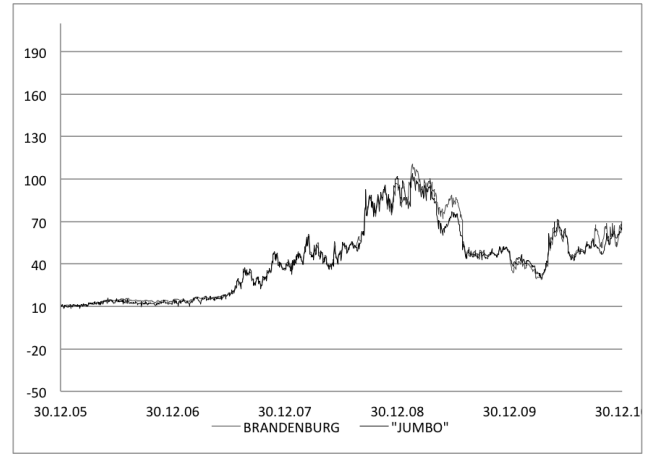

Figure 2: Brandenburg

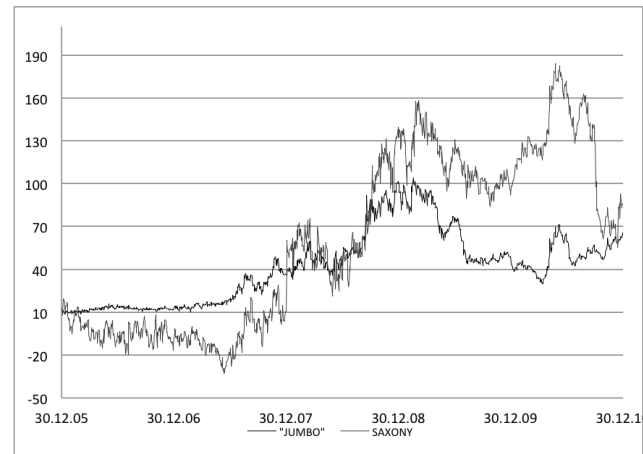

Figure 4: Saxony

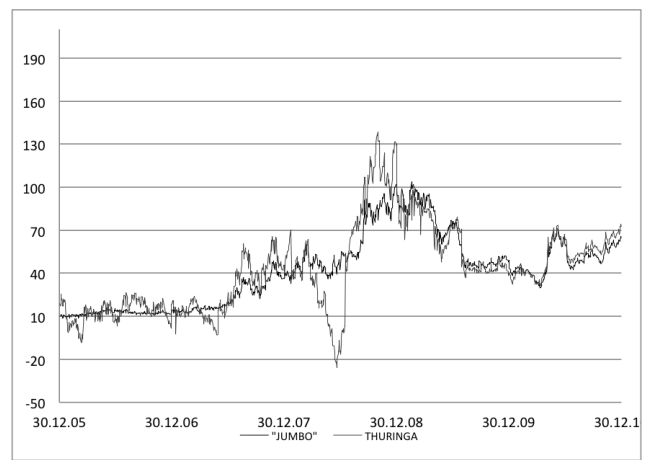

Figure 6: Thuringa

Mean yield Spreads: Bonds of East German states including Berlin over government benchmark (Bund) vs. jointly issued bonds ("Jumbos") over government benchmark (Source: Datastream, own calculations) 


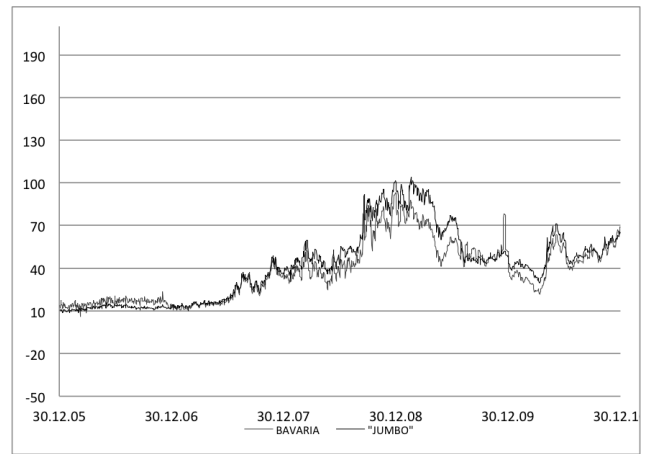

Figure 7: Bavaria

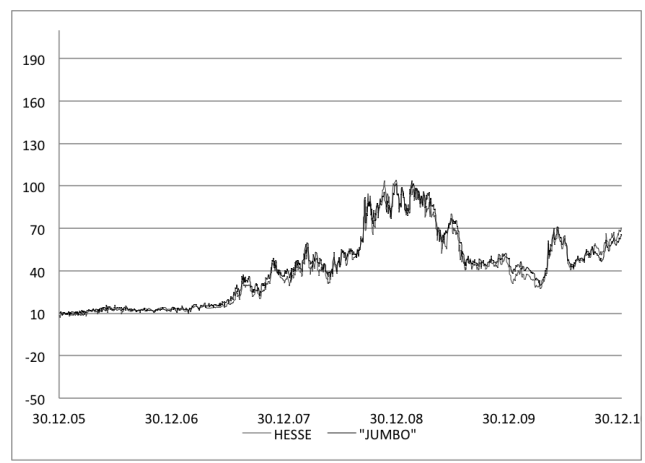

Figure 9: Hesse

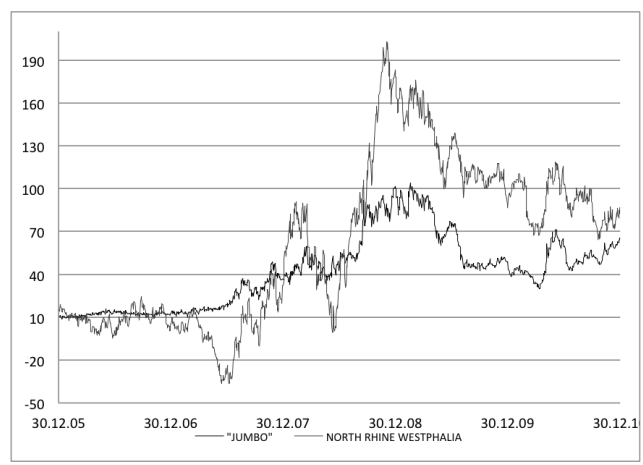

Figure 11: North Rhine Westphalia

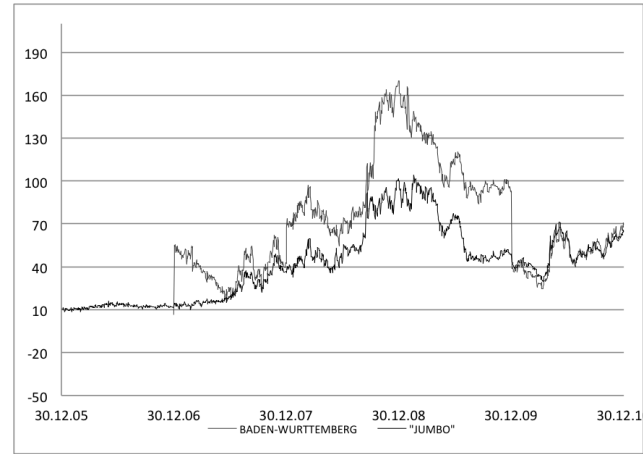

Figure 8: Baden-Wurttemberg

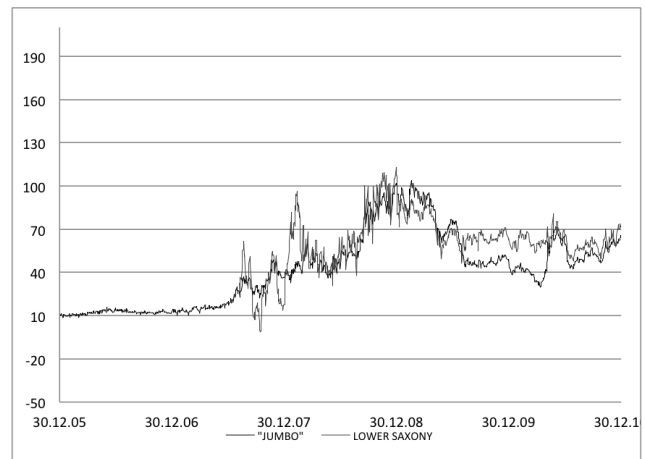

Figure 10: Lower Saxony

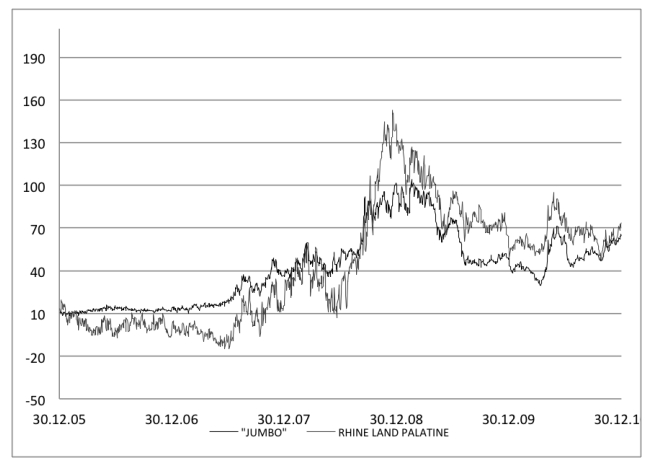

Figure 12: Rhineland Palatine

Mean yield spreads: Bonds of selected West German states over government benchmark (Bund) vs. jointly issued bonds ("Jumbos") over government benchmark (Source: Datastream, own calculations) 